\title{
頸部内頸動脈狭窄症の的確な治療に対する脳血流測定の意義
}

\author{
中川原譲二 上山憲司 $⿴$ 居礼子 \\ 武田利兵衛 中 村 博 彦
}

\section{The Significance of CBF Measurements for Precise Management of Carotid Stenosis}

by

\author{
Jyoji Nakagawara, M.D., Kenji Kamiyama, M.D., Reiko Usui, M.D., \\ Rihei Takeda, M.D., and Hirohiko Nakamura, M.D. \\ from \\ Department of Neurosurgery, Nakamura Memorial Hospital
}

Severe hemodynamic cerebral ischemia associated with carotid stenosis could be one of the difining characteristics of the high-risk group for carotid endarterectomy (CEA). Measurements of cerebral blood flow (CBF) and vascular reactivity in patients treated with CEA were analyzed to clarify the significance of preoperative evaluation of hemodynamic cerebral ischemia using CBF-SPECT.

Both the resting and acetazolamide-activated $\mathrm{rCBF}$, and the severity of the hemodynamic cerebral ischemia (Stage 0- II ) were quantified using the ${ }^{123} \mathrm{I}$-IMP ARG method and preoperative cerebral hemodynamics were compared in both symptomatic patients $(n=30)$ and asymptomatic patients $(n=24)$. Postoperative improvement of resting $\mathrm{rCBF}$ was estimated in both groups. Stage II ischemia was quantitatively defined as both a resting rCBF of less than $80 \%$ of normal mean $\mathrm{CBF}$ and a vascular reserve (VR: (acetazolamide-activated $\mathrm{rCBF} /$ Resting $\mathrm{rCBF}-1$ ) $\times$ $100 \%$ ) of less than $10 \%$. In the other 31 patients treated with CEA, postoperative hyperperfusion was investigated using CBF-SPECT within 24 hours after CEA.

Preoperatively, Stage II ischemia (hemodynamically compromised state) was observed in $20 \%$ of symptomatic patients and $8 \%$ of asymptomatic patients. A significant difference in resting $\mathrm{rCBF}$ was indicated between symptomatic patients $(31.8 \pm 6.1 \mathrm{ml} / 100 \mathrm{~g} / \mathrm{min})$ and asymptomatic patients $(37.6 \pm 6.6 \mathrm{ml} / 100 \mathrm{~g} / \mathrm{min})(\mathrm{p}<0.002, \mathrm{t}-\mathrm{test})$. Severity of hemodynamic cerebral ischemia was generally moderate in symptomatic patients. Postoperatively, a significant increase of resting $\mathrm{CBF}$ was observed in symptomatic patients but not in asymptomatic patients. In the other 31 patients treated by CEA, symptomatic hyperperfusion was observed in 3 of 4 patients with Stage II ischemia and asymptomatic hyperperfusion was indicated in 3 of 4 patients with Stage I ischemia with a VR of less than $10 \%$.

Preoperative $\mathrm{CBF}$ measurements in patients treated with CEA were significant to define severe hemodynamic cerebral ischemia (Stage II ). In patients with Stage II ischemia, brain protection should be introduced using mild hypothermia with an internal shunt system in CEA, or carotid stenting could be a safer procedure. In a subgroup with Stage II ischemia, postoperative hyperperfusion should be assessed by early CBF measurement and controlled by precise management.

(Received July 11, 2002; accepted August 2, 2002)

Key words : carotid stenosis, cerebral blood flow, hemodynamic cerebral ischemia, carotid endarterectomy, stenting

Jpn J Neurosurg（Tokyo） $11: 806-812,2002$

中村記念病院脳神経外科 $/ \bar{T} 060-8570$ 札幌市中央区南 1 条西 14 丁目〔連絡先：中川原譲二〕

Address reprint requests to: Jyoji Nakagawara, M.D., Department of Neurosurgery, Nakamura Memorial Hospital, South-1, West14, Chuo-ku, Sapporo-shi, Hokkaido 060-8570, Japan 


\section{はじめに}

頸部内頸動脈狭窄症に対する血栓内膜剝離術 (CEA) の有効性についてはすでに，NASCET（North American Symptomatic Carotid Endarterectomy Trial) ${ }^{1)}$ p ACAS (Asymptomatic Carotid Atherosclerosis Study) ${ }^{2)}$ な゙の前 向き無作為化比較試験（RCT）により確立されている.

AHA（American Heart Association）がまとめた CEA 治 療ガイドライン314)によると, 治療適応の条件としては狭 窄度のみならず外科治療の周術期リスク (morbidity and mortality）が重要で，症候性頸動脈狭窄の場合にはそれ ぞれ 70\%以上と 6\%以下，無症候性頸動脈狭窄の場合に はそれぞれ 60\%以上と $3 \%$ 以下であることが必要とさ れている。

さらに，両側の狭窄病変例や他側の内頸動脈閉塞を伴 う症例は，CEAの high risk 群とされ，周術期の対応が 問題となる ${ }^{5) 6)}$ 。一方, 頸部内頸動脈狭窄症の脳循環動態 に関するこれまでの研究によると, CEA 術前に $\mathrm{CO}_{2}$ また は acetazolamide に対する脳血管反応性の低下あるいは 脳循環予備能の低下がみられる症例では，術後にこれら の指標の改善が得られるが7)8 11)，これらの指標が高度 に低下した症例では, CEA 術後に高灌流症候群などの周 術期リスクが高まることが知られ ${ }^{12)}$ ，高度血行力学的脳

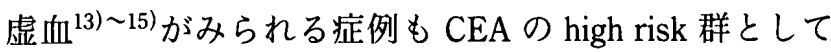
対応しなければならない。

そこで, 本研究では頸部内頸動脈狭窄症に対する脳血 流測定の意義を明確にするために，症候性頸動脈狭窄群 および無症候性頸動脈狭窄群における血行力学的脳虚血 の重症度および術前・術後における脳循環動態の改善の 程度を,脳血流の定量測定により明らかにするとともに， 術前にみられる高度血行力学的脳虚血が, 術直後の高灌 流（あるいは高灌流症候群）に，どの程度関与するかに ついて検討した。

\section{方 法}

脳血管造影による頸部内頸動脈の狭窄度が, $\mathrm{NASCET}^{1)}$ による評価方法にて $70 \%$ 以上と評価され， CEA が施行された症候性頸動脈狭窄群 30 症例（年齿 $65.8 \pm 6.8$ 歳, 男女比 $28: 2$ ), 無症候性頸動脈狭窄群 24 症例（年齢 68.5 \pm 6.1 歳, 男女比 $21: 3$ ）を対象として, 術前・術後（平均 2 週後）に N-isopropyl- $\rho-\left[{ }^{123} \mathrm{I}\right]-$ iodoamphetamine（IMP）をトレーサーとする, 安静時お よび acetazolamide 負荷時の脳血流 SPECT を施行した。 脳血流 SPECT の定量画像解析法として IMP-autora-

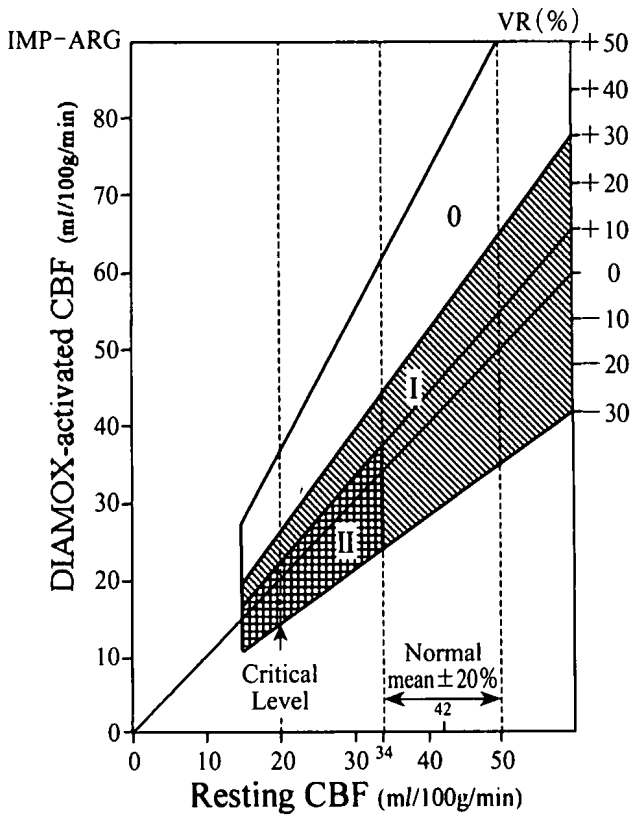

Fig. 1 Severity of hemodynamic cerebral ischemia was stratified by both resting rCBF and vascular reserve : (acetazolamide-activated $\mathrm{rCBF} /$ resting $\mathrm{rCBF}-$ 1) $\times 100 \%$ ) estimated using the ${ }^{123}$ IMPARG method

Stage $0:$ vascular reserve (VR) $>30 \%$

Stage I : resting $\mathrm{rCBF}>34 \mathrm{ml} / 100 \mathrm{~g} / \mathrm{min}(80 \%$ of the mean value of a normal volunteer), or $\mathrm{VR} \leqq 30 \%,>10 \%$

Stage II : resting $\mathrm{rCBF} \leqq 34 \mathrm{ml} / 100 \mathrm{~g} / \mathrm{min}$, and VR $\leqq 10 \%$

diography（ARG）法年)を用い，血行力学的脳虚血の定量 的重症度評価を行った。

本解析法では, IMP の挙動を 2-compartment model(組 織からのトレーサーの洗い出しを考慮したモデル）に よって解析するが，トレーサーの血液から脳への移行速 度 $(\mathrm{K} 1)$ と, 脳から血液への移行速度 $(\mathrm{k} 2)$ の比である 分布容積 $(\mathrm{Vd})(=\mathrm{K} 1 / \mathrm{k} 2)$ を一定值 $(42 \mathrm{ml} / \mathrm{m} l)$ とし, 個々の入力関数（トレーサーの動脈血中濃度）は，あら かじめ設定されている標準入力関数を動脈血 1 点採血 により較正し，決定することができる．

この方法により，トレーサー（222 MBq）投与後 20〜 40 分の間に撮像された 1 回の SPECT 画像は, トレー サー投与後 10 分後に採血された動脈血から得られる入 力関数によって, pixel by pixel $(64 \times 64)$ に脳血流定量 画像へと変換された。 acetazolamide 負荷では, トレー サーの投与 7 分前に $15 \mathrm{mg} / \mathrm{kg}$ を静注した. 脳血流定量 画像（基底核レベルの axial image）上の患側中大脳動脈 領域に関心領域（ROI）を設定し，平均脳血流量 $(\mathrm{rCBF})$ を算出した。

また， CEA 術後 24 時間以内に IMP を用いた脳血流 


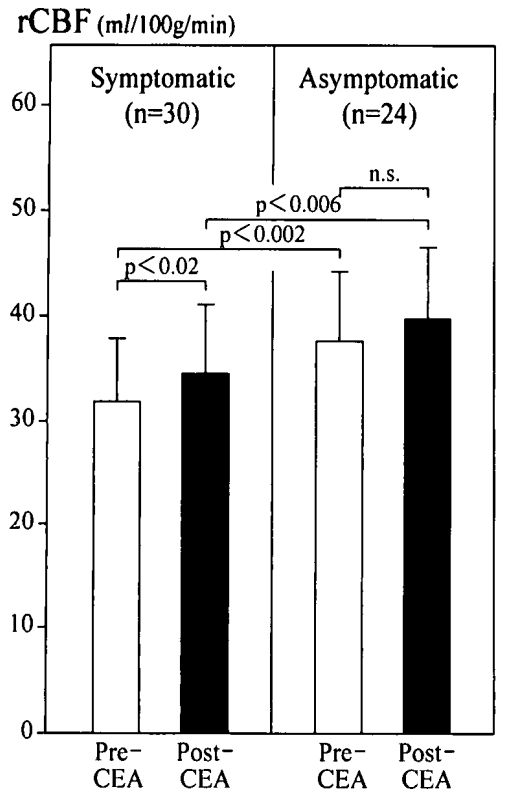

Fig. 2 Comparison of mean $\mathrm{rCBF}$ before and after CEA in symptomatic patients ( $\mathrm{n}=$ $30)$ and asymptomatic patients $(n=24)$ ( $\mathrm{rCBF}$ was quantified in the affected middle cerebral artery territories.)

A significant difference was observed in preoperative resting $\mathrm{rCBF}$ between symptomatic patients $(31.8 \pm 6.1 \mathrm{ml} / 100 \mathrm{~g} / \mathrm{min})$ and asymptomatic patients $(37.6 \pm 6.6 \mathrm{ml} / 100 \mathrm{~g} / \mathrm{min})(\mathrm{p}<0.002, \mathrm{t}$-test $)$. A significant increase of postoperative resting $\mathrm{rCBF}$ was observed in symptomatic patients $(34.4 \pm 6.6 \mathrm{ml} /$ $100 \mathrm{~g} / \mathrm{min}, \mathrm{p}<0.02, \mathrm{t}$-test) but not in asymptomatic patients $(39.7 \pm 6.8 \mathrm{ml} / 100 \mathrm{~g} / \mathrm{min}$, n.s. $)$.
SPECT により, 安静時 $\mathrm{rCBF}$ が定量された 31 症例（症 候性頸動脈狭窄群 20 症例, 無症候性頸動脈狭窄群 11 症 例，年秢 $66.7 \pm 6.6$ 歳，男女比 $29: 2)$ を対象として, 患 側中大脳動脈領域に視覚的に捉光引扎る皮質領域の高灌 流域(通常対側 ROI の脳血流よりも10\%以上脳血流が増 加した場合に捉えられる）の有無を判定し, 術前の発症 機序・術前の血行力学的脳虚血の定量的重症度 (Stage) ・術中の内頸動脈 stump pressure（内シャント チューブ挿入後に測定）と術直後の脳血流 SPECT 上の 高灌流所見 (不隱状態, 症攣発作, 脳内出血などを合併 した場合を症候性高灌流，合併しなかった場合を無症候 性高灌流とした）との関係について検討した。

血行力学的脳虚血の定量的重症度の評価基準17) は，安 静時 $\mathrm{rCBF}$ および安静時 rCBF と acetazolamide (15 mg/ $\mathrm{kg}$ ) 負荷時 $\mathrm{rCBF}$ から得られる脳循環予備能（vascular reserve：VR) : [ (acetazolamide 負荷時 $\mathrm{rCBF} /$ 安静時 $\mathrm{rCBF}-1) \times 100 \%]$ から以下のように設定された. Stage $0: \mathrm{VR}>30 \%$, Stage I : 安静時 $\mathrm{rCBF}>34 \mathrm{ml} / 100 \mathrm{~g} / \mathrm{min}$ （正常群平均 $42 \mathrm{ml} / 100 \mathrm{~g} / \mathrm{min}$ の $80 \%$ ）またはVR $30 \%,>10 \%$, Stage II : 安静時 $\mathrm{rCBF} \leqq 34 \mathrm{ml} / 100 \mathrm{~g} / \mathrm{min}$ かつ VR $\leqq 10 \%$ (Fig. 1).

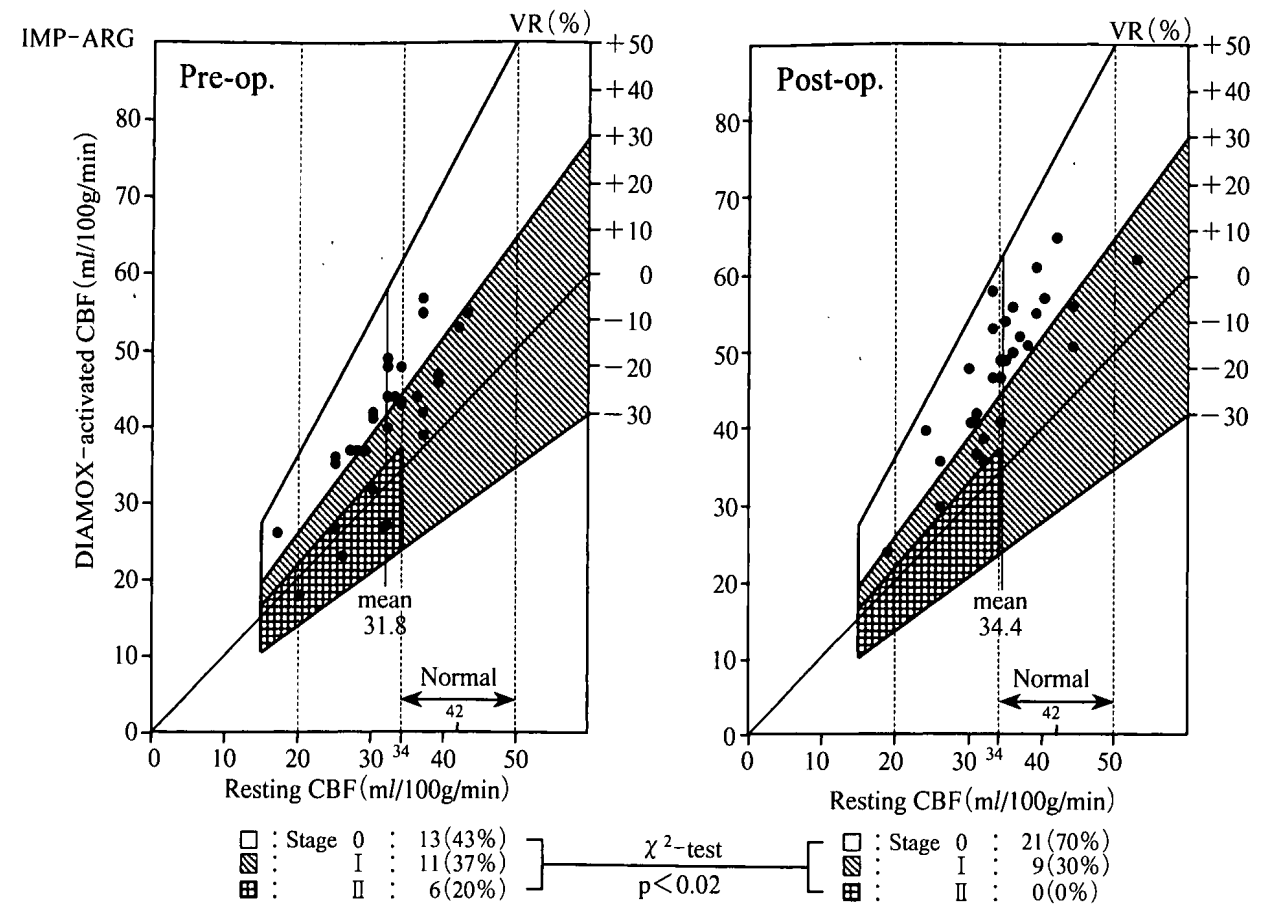

Fig. 3 Comparison of severity of hemodynamic cerebral ischemia in symptomatic patients

Preoperatively, Stage II ischemia (hemodynamically compromised state) was observed in $20 \%$ and the severity of hemodynamic cerebral ischemia was significantly improved after CEA $\left(\mathrm{p}<0.02, \chi^{2}\right.$-test $)$. 

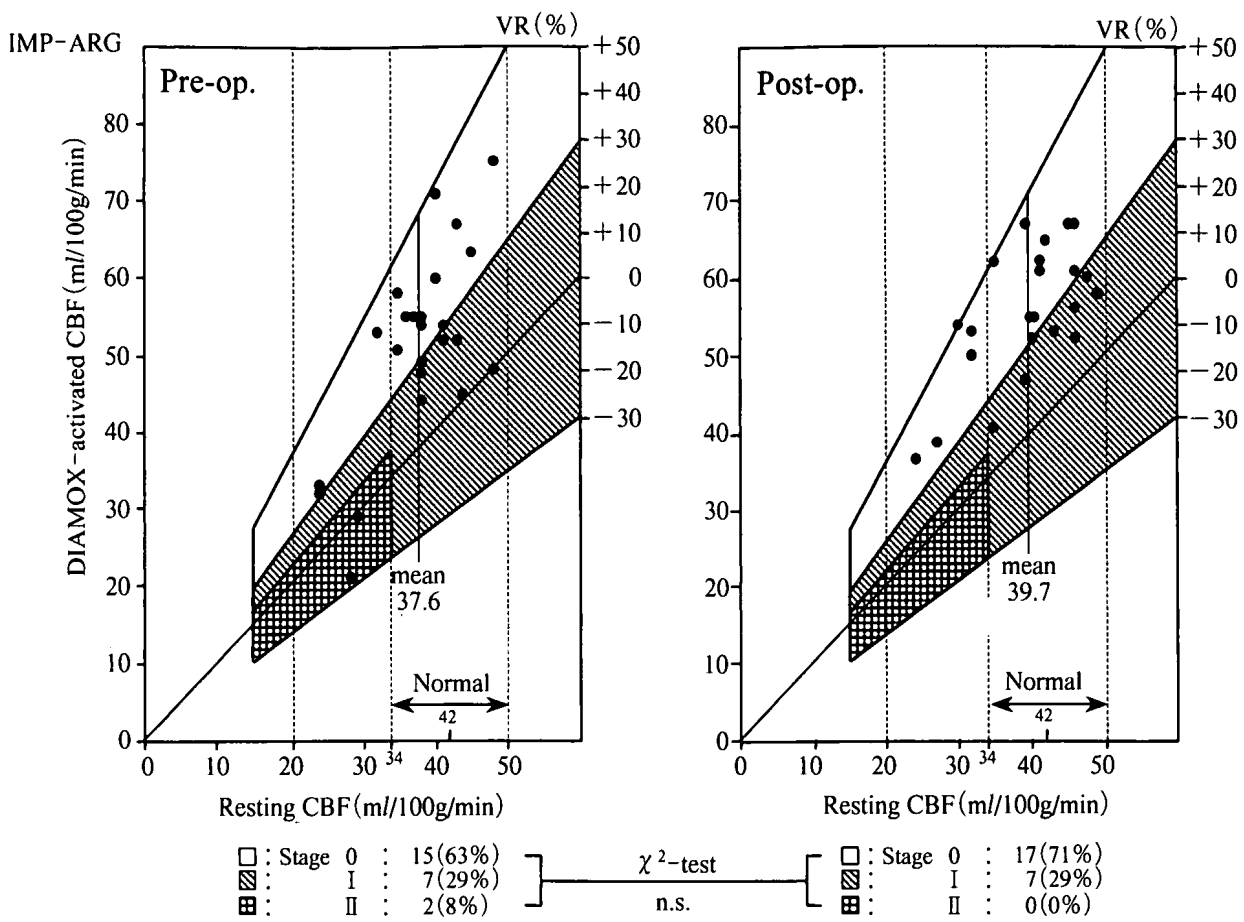

Fig. 4 A comparison of the severity of hemodynamic cerebral ischemia in asymptomatic patients

Preoperatively, Stage II ischemia (hemodynamically compromised state) was observed in $8 \%$ of the patient's and the severity of hemodynamic cerebral ischemia was not significantly improved after CEA ( $\chi^{2}$-test $)$.

Table 1 Correlations of clinical categories and postoperative hyperperfusion

\begin{tabular}{lrrr}
\hline Clinical categories & $\mathrm{n}$ & \multicolumn{2}{c}{ Postoperative hyperperfusion } \\
\cline { 3 - 4 } & & & + \\
\hline Symptomatic & 13 & 8 & 5 \\
Hemodynamic ischemia & 7 & 7 & 0 \\
A to A embolism & 11 & 10 & 1 \\
Asymptomatic & &
\end{tabular}

\section{結 果}

\section{1 術前・術後 (平均 2 週後) の血行力学的脳虚血 の定量的重症度評価}

術前の患側中大脳動脈領域の安静時 $\mathrm{rCBF}$ は，症候性 病変群 $(\mathrm{n}=30)$ では $31.8 \pm 6.1 \mathrm{ml} / 100 \mathrm{~g} / \mathrm{min}$, 無症候性 病変群 $(\mathrm{n}=24)$ では $37.6 \pm 6.6 \mathrm{ml} / 100 \mathrm{~g} / \mathrm{min}$ と測定され, 両群の間に有意差を認めた ( $\mathrm{p}<0.002, \mathrm{t}$ 検定)（Fig. 2). また血行力学的脳虚血の Stage 分類では, 症候性病変群 は, Stage 0:13 (43\%), Stage I : $11(37 \%)$, Stage II : $6(20 \%)$, 無症候性病変群は, Stage 0: $15(63 \%)$, Stage I $: 7$ (29\%), Stage II : $2(8 \%)$ と分類され, 両群間に は有意差を認めないものの ( $\chi^{2}$ 検定 $)$, 血行力学的に問 題となる Stage II の割合は，症候性病変群で $20 \%$, 無症 候性病変群で 8\%であった（Fig. 3，4）。すなわち無症候 性病変群では, 安静時 $\mathrm{rCBF}$ の低下は軽度で, 重症の血
行力学的脳虚血 Stage II の合併は, 症候性病変に比較し て低率であった。

$\because$ 術後の患側中大脳動脈領域の安静時 $\mathrm{rCBF}$ は, 症候性 病変群 $(\mathrm{n}=30)$ では $34.4 \pm 6.6 \mathrm{ml} / 100 \mathrm{~g} / \mathrm{min}$, 無症候性 病変群 $(\mathrm{n}=24)$ では $39.7 \pm 6.8 \mathrm{ml} / 100 \mathrm{~g} / \mathrm{min}$ と測定され, 両群の間に有意差を認めた（ $<<0.006, t$ 検定）（Fig. 2). 症候性病変群では, 術後の安静時 $\mathrm{rCBF}$ は術前值よりも 有意に改善し $(p<0.02, t$ 検定), 血行力学的脳虚血の Stage 分類では術後 Stage 0:21 (70\%), Stage I : 9 (30\%), Stage II : $0(0 \%)$ と分類され, 術前分類に比較 して有意に改善した（ $\chi^{2}$ 検定）（Fig. 3）。一方，無症候 性病変群では, 術後の安静時 $\mathrm{rCBF}$ は術前値との間には 有意差がなく, 血行力学的脳虚血の Stage 分類では, 術 後 Stage 0:17 (71\%), Stage I $: 7(29 \%)$, Stage II $: 0$ (0\%) と分類され, 術前分類との間には有意差がなかっ た (Fig. 4). 


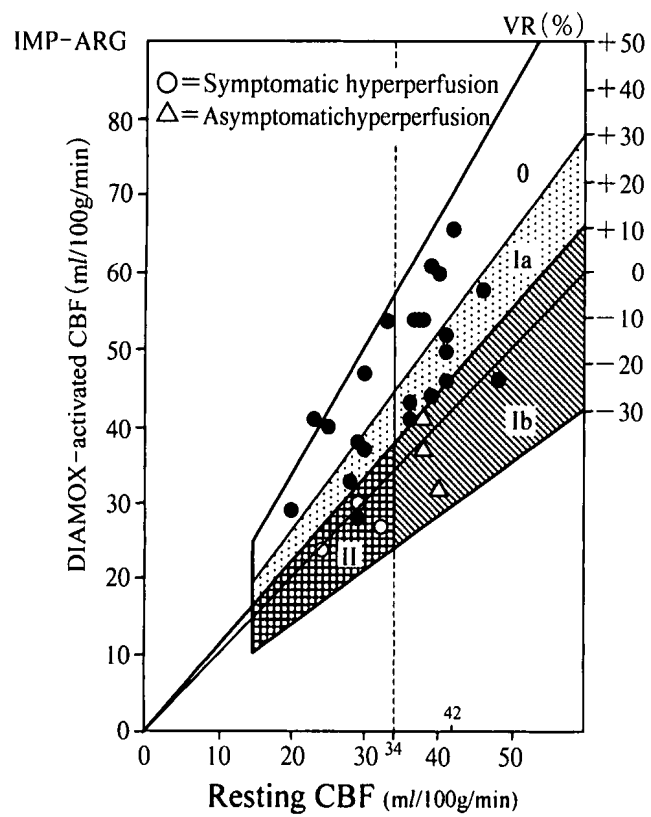

Fig. 5 Severity of hemodynamic cerebral ischemia and postoperative hyperperfusion

Symptomatic hyperperfusion was observed in 3 of 4 patients with Stage II ischemia and asymptomatic hyperperfusion was indicated in 3 of 4 patients with Stage I ischemia with a VR of less than $10 \%$ (Stage I b).

\section{2 術直後の脑血流 SPECT 上の高灌流所見に関 係する因子}

\section{1. 術前の発症機序との関係}

術後に高灌流所見が認められた 6 症例中 5 例は症候 性病変群では，いずれも発症機序が血行力学的脳虚血発 作と診断された症例であった(Table 1)。術前に血行力学 的脳虚血発作が認められた症例では，術後に高灌流を呈 する危険性が高い傾向にあったが，統計学的には有意で はなかった $(\mathrm{p}=0.06)$. 無症候性病変群の 1 例に認めた 術後の高灌流所見は無症候性で，術前の血行力学的脳虚 Ifllの Stage 分類は I で, VR が 10\%以下であった。

\section{2. 術前の血行力学的脳虚血の定量的重症度との関係}

術前 Stage 0 群（13 例）では，術直後に高灌流所見を 認めた症例はなかった (Fig. 5)。術前 Stage I 群 (14 例) では，VR が 10\%以上（Stage I a）の 10 例（1a）では， 術直後に高灌流所見はみられなかったが，VRが $10 \%$ 以 下（Stage I b）の 4 例中 3 例（75\%）に，無症候性の高 灌流所見が認められた。術前 Stage II 群 (4 例) では，術 直後に 4 例中 3 例 $(75 \%)$ に症候性の高灌流所見が認め られた。

\section{3. 術中の内頸動脈 stump pressure との関係}

術直後に高灌流所見が認められた 6 症例と認められ なかった 25 例との間では, 内頸動脈（ICA） stump pres-

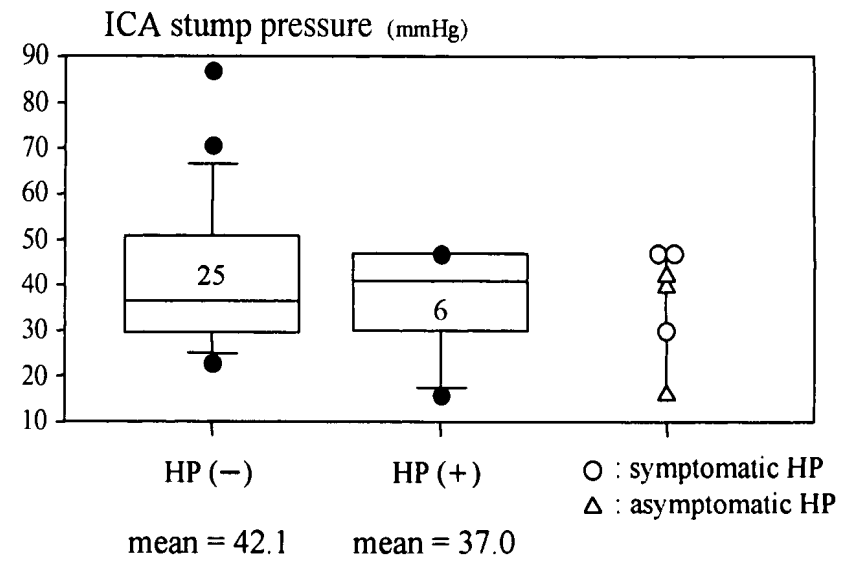

Fig. 6 Intraoperative ICA stump pressure and postoperative hyperperfusion (HP)

There was no difference between mean ICA stump pressure in patient's with either of without postoperative hyperperfusion $(\mathrm{p}=0.5)$.

sure に有意差はなかった（ $\mathrm{p}=0.5 ， \mathrm{t}$ 検定）（Fig. 6)。ま た術直後に高灌流所見が認められた症例の比率は，全症 例に対して 6/31 (19\%) であったが, ICA stump pressure が $50 \mathrm{mmHg}$ 以下の群では 6/23 (26\%), $40 \mathrm{mmHg}$ 以下 の群では $2 / 17(12 \%), 30 \mathrm{mmHg}$ 以下の群では $1 / 8(13 \%)$ となり，ICA stump pressure の低下と術直後の高灌流所 見の間にも関連性は認められなかった。

\section{考 察}

症候性頸部内頸動脈狭窄症と無症候性頸部内頸動脈狭 窄症の脳循環動態を比較した研究は少なく，両群の間に どのような違いがあるかはこれまで不明であった ${ }^{18)}$ 。こ れまでの報告では，症候性病変群に対する CEA の術前 に, $\mathrm{CO}_{2}$ または acetazolamide に対する脳血管反応性の低 下，あるいは脳循環予備能の低下がみられる症例では, 術後にこれらの指標の改善が得られたとされで 11), 安静 時脳血流量の改善については, 必ずしも明確にされては いない.

われわれが行った定量的脳血流測定の結果を検討した ところ, 術前では両病変群間の安静時脳血流量に有意差 が確認され, 術後では症候性病変群で安静時脳血流量が 有意に改善したのに対して，無症候性病変群では有意な 改善は得られなかった。一方, 血行力学的脳虚血の Stage

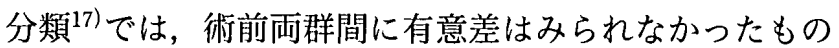
の, 重症の血行力学的脳虚血 Stage II の合併は, 症候性

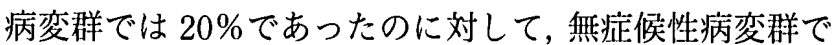
は $8 \%$ 程度にとどまった。 また, 術後の血行力学的脳虚 血の Stage 分類では, 症候性病変群で術前に対して有意 な改善がみられたのに対して, 無症候性病変群では有意 
な改善は得られなかった。これらの所見から，症候性病 変群における脳循環動態の特色として, 血行力学的脳虚 血の程度が，より高度であることが示唆された ${ }^{13) \sim 15)}$. すなわち症候性病変群では, 患側の脳灌流圧の低下によ る脳血流量の低下がより高度であり，重症の血行力学的 脳虚血 Stage II を合併する割合が比較的多く，周術期に 脳虚血が増悪するリスクが, 無症候性病変群に比較して 高いと考えられた．血行力学的脳虚血 Stage II と診断さ れた場合には，術中の血流遮断に基づく脳虚血の増悪に 対しては脳保護対策が重要であり，内シャントチューブ の使用 ${ }^{19)}$ や軽度低体温麻酔20)などを考慮する必要があ る.

以上より，頸部内頸動脈狭窄症に対する脳血流測定の 第 1 の意義は, 高度の血行力学的脳虚血により周術期リ スクの高い subgroup を検出するところにあり, 血行力学 的脳虚血の定量的重症度評価 ${ }^{17)}$ は，臨床的にきわめて有 用であると考えられた。

次に, 脳循環動態の観点から, CEA 術直後の高灌流 (高灌流症候群 ${ }^{21)}$ ) について考察する。一般に CEA の術 直後にみられる高灌流の機序については, CEA 直後に増 大する脳灌流圧に対して，細動脈レベルの脳実質血管に おける脳血流の自動調節能（血管収縮）が機能しないた めに，脳血流の break through（高灌流）が生じると考え られている。

われわれのデータでは, 術前 Stage I の症例のうち VR が $10 \%$ 以下（Stage I b）の 4 例中 3 例 (75\%) におい て, 術直後に無症候性の高灌流所見が認められ，術前 Stage II の 4 症例では，術直後に 3 例 $(75 \%)$ において 症候性の高灌流所見が認められ，このうち 5 例の発症機 序が血行力学的脳虚血発作であった。いずれの場合も， VR が $10 \%$ 以下で脳循環予備能が喪失した状態（脳実質 血管が最大限に拡張した状態）において，術後高灌流が 高率に生じることが判明した。この所見は，脳循環予備 能が坆失した状態では, CEA 直後に増大する脳灌流圧に 対して脳実質血管の収縮による脳血流の自動調節能が機 能しない可能性が高いことを示唆している。すなおち, 術前の血行力学的脳虚血の重症度評価において, Stage I で VR が 10\%以下，あるいは Stage II.と判定された場合 には, CEA 直後に高率に高灌流が生じる可能性があると 考えられた。これらの症例では, 術後の脳灌流圧の上昇 に伴う高灌流症候群を予測し, 術後血圧の曒重なコント ロールや不穞状態に対する的確な対処，全身麻酔の継続 による鎮静などの対処が必要となる ${ }^{12)}$.

一方, 本研究においては術中の ICA stump pressure と 術後の高灌流所見との間に関連性を見出すことはできな
かった。この結果については, ICA stump pressure が, 順行性血流遮断時における, 同側の眼動脈やウィリス動 脈輪を介する側副血行路の逆行性動脈圧を反映する指標 であり，順行性の脳灌流圧低下に対する脳循環予備能の 低下あるいは变失を直接的に反映する指標ではないこと によると考えられた。

以上より，頸部内頸動脈狭窄症に対する脳血流測定の 第 2 の意義は, 術後の高灌流を生じる可能性の高い subgroup (脳循環予備能の喪失がみられる群) を検出すると ころにあり，この場合にも血行力学的脳虚血の定量的重 症度評価は, 臨床的にきわめて重要であると考えられた。

最後に, 高度の血行力学的脳虚血を伴う頸部内頸動脈 狭窄症例に対する治療方針について考察する。一側性の 頸部内頸動脈狭窄症で, 高度の血行力学的脳虚血 Stage IIがみられる症例では，原則として CEA を選択するが, 術中に脳虚血を増悪させないことが重要と考えられ，術 中血圧の維持ばかりでなく，血流の遮断に対して一時的 な軽度低体温療法を用いることで脳を保護することや， 内シャントチューブの使用により, 内膜剝離中の脳血流 を保持することにより，周術期のリスクを軽減すること が重要と考えられる．両側性の頸動脈病変のうち，対側 の頸部内頸動脈が閉塞している場合には, CEA 術中の血 流遮断により雨側大脳半球の脳虚血を生じる可能性が高 いため，CEAに代えて stent を用いた血管挔張術を第一 選択とし，周術期のリスクを軽減することが重要と考え られる ${ }^{22)}$. また両側性の頸部内頸動脈狭窄症例では，第 一段階の治療として血行力学的脳虚血 Stage II がみられ る側（通常は症候性病変側）の頸部内頸動脈狭窄に対し て, stent を用いた血管挔張術を選択し，第二段階の治療 として対側の狭窄病変に対して，CEA または stentを用 いた血管拡張術を選択し，二期的治療により周術期のリ スクを軽減することが重要と考えられる。

頸部内頸動脈狭窄例に対する脳血流測定の意義は，高 度の血行力学的脳虚血を的確に診断してCEAの high risk 群を見出すところにあり, CEA に伴う周術期のリス クを評価し，治療に伴うリスクを軽隇するための集学的 治療計画の策定に結びつけることが重要である.

\section{文 献}

1) North American Symptomatic Carotid Endarterectomy Trial Collaborators: Beneficial effect of carotid endarterectomy in symptomatic patients with high-grade carotid stenosis. N Engl J Med 325: 445-453, 1991.

2) Executive Committee for the Asymptomatic Carotid Atherosclerosis Study : Endarterectomy for asymptomatic carotid artery stenosis. JAMA 273: 1421-1428, 1995.

3) Moore WS, Barnett HJM, Beebe HG, Bernstein EF, 
Brener BJ, Brott T, Caplan LR, Day A, Goldstone J, Hobson RW II, Kempczinski RF, Matchar DB, Mayberg MR, Nicolaides AN, Norris JW, Ricotta JJ, Robertson JT, Rutherford RB, Thomas D, Toole JF, Trout HH III, Wiebers DO: Guidelines for carotid endarterectomy: A multidisciplinary consensus statement from the Ad Hoc Committee, American Heart Association. Stroke 26: 188-201, 1995.

4) Biller J, Feinberg WM, Castaldo JE, Whittemore AD, Harbaugh RE, Dempsey RJ, Caplan LR, Kresowik TF, Matchar DB, Toole JF, Easton JD, Adams HP Jr, Brass LM, Hobson RW II, Brott TG, Sternau L: Guidelines for carotid endarterectomy: A statement for healthcare professionals from a special writing group of the stroke council, American Heart Association. Stroke 29: 554-562, 1998.

5) Gasecki AP, Eliasziw M, Ferguson GG, Hachinski V, Barnett HJM: Long-term prognosis and effect of endarterectomy in patients with symptomatic severe carotid stenosis and contralateral carotid stenosis or occlusion: Results from NASCET. J Neurosurg 83: 778-782, 1995.

6) AbuRahma AF, Robinson P, Holt SM, Herzog TA, Mowery NT: Perioperative and late stroke rates of carotid endarterectomy contralateral to carotid artery occlusion: Results from a randomized trial. Stroke 31: 1566-1571, 2000.

7) Schroeder T, Sillesen H, Engell HC: Hemodynamic effect of carotid endarterectomy. Stroke 18: 204-209, 1987.

8) Cikrit DF, Burt RW, Dalsing MC, Lalka SG, Sawchuk AP, Waymire B, Witt RM : Acetazolamide enhanced single photon emission computed tomography (SPECT) evaluation of cerebral perfusion before and after carotid endarterectomy. J Vasc Surg 15:747-754, 1992.

9) Russell D, Dybevold S, Kjartansson O, Nyberg-Hansen R, Rootwelt $\mathrm{K}$, Wiberg $\mathrm{J}$ : Cerebral vasoreactivity and blood flow before and 3 months after carotid endarterectomy. Stroke 21: 1029-1032, 1992.

10) Cikrit DF, Dalsing MC, Harting PS, Burt RW, Lalka SG, Sawchuk AP, Solooki B: Cerebral vascular reactivity assessed with acetazolamide single photon emission computer tomography scans before and after carotid endarterectomy. Am J Surg 174: 193-197, 1997.

11) Hosoda, K, Fujita S, Kawaguchi T, Shose Y, Shibata Y, Tamaki $\mathrm{N}$ : Influence of degree of carotid artery stenosis and collateral pathways and effect of carotid endarterectomy on cerebral vasoreactivity. Neurosurgery 42:988-
$995,1998$.

12) Hosoda K, Kawaguchi T, Shibata $Y$, Kamei M, Kidoguchi K, Koyama J, Fujita S, Tamaki N: Cerebral vasoreactivity and internal carotid artery flow help to identify patients at risk for hyperperfusion after carotid endarterectomy. Stroke 32: 1567-1573, 2001:

13) Baron JC, Bousser MG, Rey A, Guillard A, Comar D, Castaigne $\mathrm{P}$ : Reversal of focal "misery perfusion syndrome" by extra-intracranial arterial bypass in hemodynamic cerebral ischemia: A case study with ${ }^{15} \mathrm{O}$ positron emission tomography. Stroke 12: 454-459, 1981.

14) Powers WJ: Cerebral hemodynamics in ischemic cerebrovascular disease. Ann Neurol 29: 231-240, 1991.

15）中川原譲二: SPECT と PET. 山口武典, 内山真一郎, 松 本昌泰, 峰松一夫, 高木 誠編 : 脳卒中学 The Frontiers of Strokology. 東京, 医学書院, 1998, pp. 139-154.

16) Iida $H$, Itoh $H$, Nakazawa $M$, Hatazawa J, Nishimura $H$, Onishi Y, Uemura $\mathrm{K}$ : Quantitative mapping of regional cerebral blood flow using iodine-123-IMP and SPECT. $J$ Nucl Med .35:2019-2030, 1994.

17）中川原譲二：脳虚血の臨床画像診断. 脳神経 51 : 502513, 1999.

18）山根冠児, 島 健, 岡田芳和, 西田正博, 畠山尚志, 山 中千恵, 福田 稔, 豊田章宏: 無症候性内頸動脈狭窄例 に対する血栓内膜摘除術の評価一無註候性脳血管障害の 外科治療をどうするか. The 16th Meeting of the Mt. Fuji Workshop on CVD 講演集, 東京, にゅーろん社, 1998, pp. 182-184.

19) Halsey JH Jr: Risks and benefits of shunting in carotid endarterectomy. Stroke 23: 1583-1587, 1992.

20）林 成之：脳低温療法。端和夫, 上出廷治監：脳卒中 臨床マニュアル．東京，シュプリンガー・フェアラーク 東京, 1998, pp. 129-143.

21) Sundt TM Jr: Correlation of cerebral blood flow measurements and continuous electroencephalography during carotid endarterectomy and risk-benefit ratio of shunting. in Wood $\mathrm{JH}(\mathrm{ed})$ : Cerebral blood flow: Physiologic and clinical aspects. New York, Magrow-hill, 1987, pp. 679-692.

22) Malek AM, Higashida RT, Phatouros CC, Lempert TE, Meyers PM, Smith WS, Dowd CF, van Halbach V: Stent angioplasty for cervical carotid artery stenosis in high-risk symptomatic NASCET-ineligible patients. Stroke 31: 3029-3033, 2000.

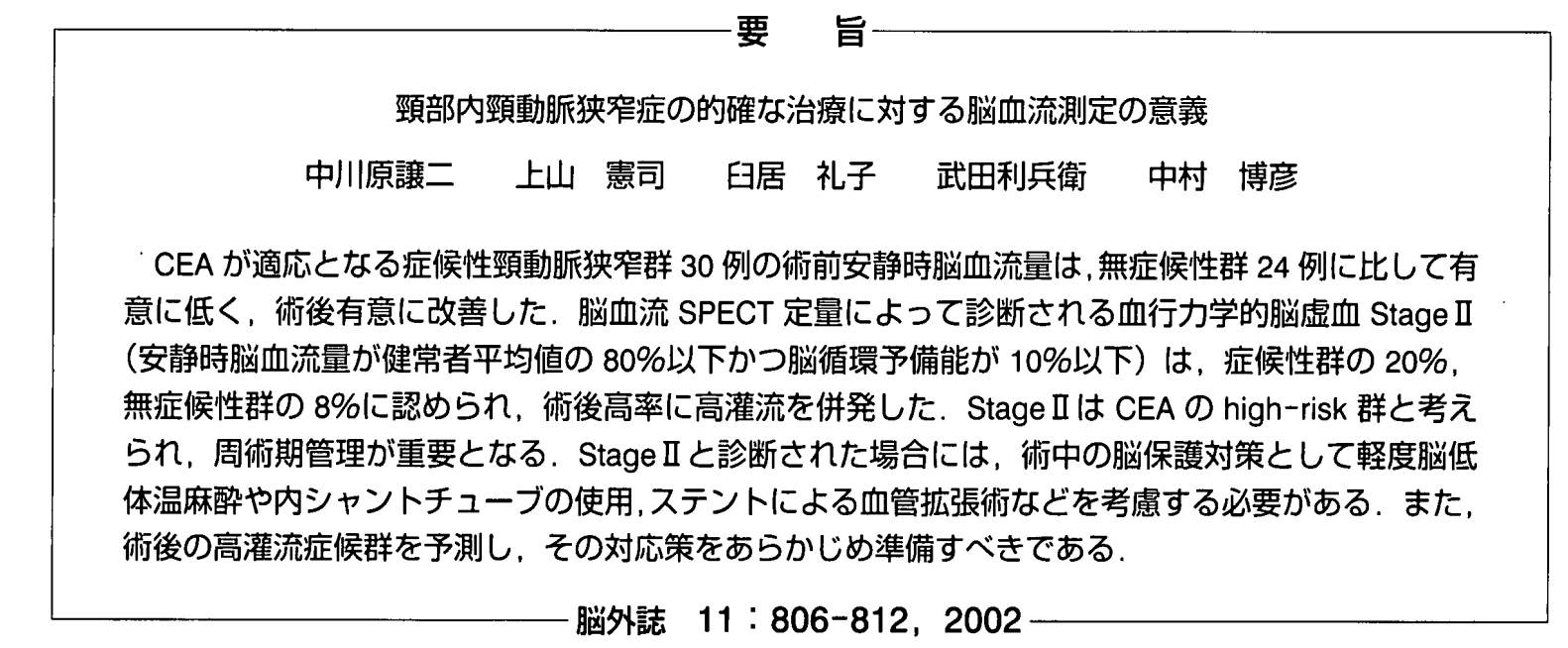

